\title{
CRUSADE AND ITS EFFECT ON THE EAST AND THE WEST
}

\author{
Ahmad Sahide \\ University of Gadjah Mada, Yogyakarta
}

\begin{abstract}
The Crusade is an important part of the history of Islamic thought, development, culture and civilization. The Crusade which changed the path of human historical development, especially of the Islamic world, had a major influence on the encounter between the West and the East (the Islamic world) today. By understanding the history, the Crusade, we can find the correlation of the hegemony of the Western countries, especially between the United States and the Islamic world today, especially in the Middle the East region. the Western presence in all aspects of life of the contemporary Islamic world, which is far left behind, has historical relevance of the Crusade. This paper seeks to review the Crusade and its influence on the development of the contemporary Islamic world and the West.
\end{abstract}

Keywords: Crusade, encounter, Islamic world.

\section{INTRODUCTION}

The Crusade was a form of encounter between the West (Europe) and the East (Islamic world). The encounter, which shed the blood of thousands of human beings without feeling guilty or innocent on the parties involved in war because it was regarded as one of God's commandments. James Turner Johnson referred to it as the holy war, a war that has the power to shed blood, the conflicts that have strong social, motivational, and ideological relationship with a great religious tradition. In the Western culture, the idea of a holy war appeared in three major historical contexts: the Old Testament, the Crusade and the religious wars in the post-reform era (James Turner Johnson, 2002).

The first encounter between Europeans and Islam occurred as a result of the expansion policies of the new Muslim state, which was formed after the passing of the Prophet Muhammad in 632. A century later, Muslims had crossed the mountain range between France and Spain and conquered territories stretching from northern India to southern France (Carole Hillendbrand, 2005). The encounters which were also regarded as a conquest were fierce battles, a bell awakening the Muslims and the Arabs at the beginning of $7^{\text {th }}$ Century, and a sign of destruction of the Sasanian and Roman Empire that enjoyed the glory days before the arrival of Islam (Hugh Kennedy, 2008). The 
flow of expansion was increasingly unstoppable. Islam made the West anxious and frightened to be ruled. Finally, Crusade was inevitable (M. Abdul Karim, 2009). The idea of the Crusade is what I will describe further in this paper to determine the factors that contribute to the war in the name of the God as well as the extent of its influence on life for the people of the East and the West that lasts until today.

The Crusade which is derived from the word "Cross" (Crux in Latin) was a military expedition that took place approximately three hundred years, from 11 th through the 13th century, with the victory on both sides alternately. The Crusade was a movement of all Christians in Europe to fight the Muslims in Palestine repeatedly aimed at liberating the holy land from Muslim rule, and building churches and Latin empire in the East. The Europeans who fought in this battle wore the Cross sign on their right chest as a symbol of the sanctity of their cause. Thus it is called the Crusade (Jatmika Sidik, 2004).

This war began when Emperor Alexus Comnesus appealed to Pope Urban II in 1095 to help him, because his power in Asia had been attacked by the Saljuks along the coast of Marmora. The Muslims attacked the power that threatened Constantinople. Upon request and petition the Emperor Alexus, on 26 November 1095, Pope Urban delivered his speech at Clermont, the South Eastern part of France, and commanded Christians to "Enter the neighborhood of the Holy Sepulchre, capture it from the evil people and hand it back to them". The evil people in question were the Muslim rulers (Saljuk). Perhaps, it was the most influential speech ever delivered by a Pope throughout recorded history. People who were there shouted slogans Deus Vult (God wills) while raising their arms. In the spring of 1097, 150,000 men, most of them were Franks, Norman, and some ordinary people welcomed the Pope's call to gather in Constantinople (Phillip K. Hitti, 2008). At that moment the drums of the Crusade began. Bainton (in James Turner Johnson, 2002), based on his study of the Puritan revolution in England, characterized the idea of the crusading idea as follows:

"The crusading idea requires that the cause of war be sacred (and there is no cause more sacred than religion), that the war be fought because of God and with His help, the Crusaders are pious and the enemies ungodly, that the war will be executed without mercy. "

There are a great deal of opinions regarding the causes of the Crusade. Abdul Karim, a Professor of Islamic History at UIN Sunan Kalidjaga Yogyakarta, for example, mentioned that the Crusade happened because of religion, politics, economics (trade), psychology, etc. (M. Abdul Karim, 2009). Philip K. Hitti 
explained the geographical facts about the differences between the East and the West can only be considered as an important factor of the Crusade when put next to conflicts between religions, tribes, nations and language differences. In fact, the Crusade is specifically described as the reaction of Christians in Europe against Muslims in Asia, which had attacked and controlled the Christian regions since 632, not only in Syria and Minor Asia, but also in Spain and Sicily. There were various things that caused the Crusade, some of which can be mentioned here i.e. the tendency of a nomadic lifestyle and militaristic of the German Teutonic tribes who had changed the map of Europe since they entered the stage of history; and the destruction of the Holy Sepulchre belonging to the church, a place of European pilgrimage whose keys had been handed over in 800 to Charlemagne with blessing of the Bishop of Jerusalem by al-Hakim (Philip K. Hitti, 2008).

The hatred, anger, and hostility of the Christian Europeans against Islam had begun since the time of Caliph al-Hakim bin Amrillah (996-10214 M), the $6^{\text {th }}$ ruler of Fatimid dynasty who destroyed the Holy Sepulchre (a holy church in Jerusalem) and the Muslim rulers of the Turkish Saljuks who interfered and treated Christian pilgrims to Jerusalem poorly (M. Abdul Karim, 2009). The Pope and kingdoms in Europe received news about the damage to the reputation of the Islamic ruler, al-Hakim, at the time. Al-Hakim's actions are what is usually considered a factor drove the growing desire of the European Christians to launch the first Crusade to protect what they regarded as holy places of Christians. During the first centuries of Muslim rule, Christian pilgrims from Europe could usually visit the holy places of their religion in Jerusalem and the Holy Land. They traveled by land through the Balkans, Anatolia, and Syria or by sea to Egypt or Palestine (Carole Hillendbrand, 2005).

Pilgrimage, for Christians, has an important role for their piety by visiting the holy places and respecting the sacred historical objects for salvation. Jerusalem, the center of the birth of Christianity, is a symbol of the city of God, so this place is sacred (Jatmika Sidik, 2004). Karen Armstrong (2000) referred to Jerusalem as the city of the three faiths.

Crusade occurred because of many factors, such as religion, politics, economics (trade), psychology, etc., but politics is the most dominant factor as the trigger of this war. It can be seen from how this war began when Emperor Alexus Comnesus appealed to Pope Urban II in 1095 to help him, because his power in Asia had been attacked by the Saljuks along the coast of Marmora. Where the Muslims attackers were a threat to Constantinople. Other indicator is that the war occurred because of the loss of freedom of the 
Christians to perform a pilgrimage to Jerusalem. At the time of Bani Fatima's reign of these areas, Christians had the freedom to perform pilgrimage and worship there. However, when the power was taken over by the Saljuks, the Christian pilgrimage became depressed and the road even closed altogether. Apart from that, the Pope (Churches of the West) had a desire to control the entire Messiah World and the ideals of European Christians to establish the Kingdom throughout the East (Jatmika Sisik, 2004).

\section{CRUSADE IN HISTORY TIMELINE}

Earlier in this paper it was mentioned that the Crusade lasted for approximately three centuries. However, the classification and division of the Crusade to the exact number, such as seven to nine times, are not satisfactory. It is because the war continued to occur and there were no clear boundaries between one war and the next. A more logical division would be started from the first conquest period until 1144, when Atabegh Zangi from Mosul took back the city of Ruha; second, a period when Muslims put staunch resistance started by Zangi, and reached its peak during the Salah al-Din (Saladin); third, a period of civil wars and skirmishes between Syrian-Egyptian Dynasty Ayyubiayah and Mamluks in Egypt, which ended in 1291, when the Crusaders lost their stronghold in mainland Syria (Phillip K. Hitti, 2008). Graham E. Fuller (2011) called the Crusade as something that is closer to the 'clash of civilizations' (The Crusade was probably the closest thing to a "civilizational conflict" ...).

\section{FIRST CRUSADE}

The burning spirit to expel the Muslims from Palestine and supported by Congress Clearmont in 1095 in France, then, the Crusaders were comprised of not less than one hundred thousand troops with a full arsenal and six hundred thousand more comprised of the pastors and children Graham E. Fuller, 2011). The first Crusade, although launched with a number of leaders in the field, including Raymond of Toulouse, Bohemond of Sicily, and Godfrey of Bouillon, achieved significant military success when they were on a journey through Anatolia. The Franks conquered the capital of the Seljuq in Iznik in June 1097, and made the Seljuq army under the leadership of Sultan Qilij Arslan suffer a massive defeat in the battle Dorylaeum in July of the same year. Upon arriving in Antioch, northern Syria, the Crusaders besieged the city in October 1097. Finally, Antioch fell to the Crusaders in June 1098 and in January the following year (1099) United Antioch inaugurated under the leadership of the ruling Norman, Bohemond, from Sicily. The main target Jerusalem - captured on July 15, 1099 and Godfrey of Bouillon became the first ruler there (Carole Hillendbrand, 2005). 
The invaders stormed the city, killing all the inhabitants without distinction of age and sex so that the pile head, arms, and feet could be seen all over the streets and squares of the city (Philip K. Hitti, 2008). There were 70,000 human lives were lost to successfully occupy the city of Jerusalem, and also the Eastern Christians never agreed with the Crusaders (Jatmika Sidik, 2004). The attitude of Muslims in response to the Crusade was initially apathetic as they were busy with internal problems. The early decades of the twelfth century were a period of divisions that occurred on a large scale among the Muslims. The Crusaders, who faced the disunited Muslims became stronger so that the first decade of the early twelfth century was the decade of takeover of most ports in the Eastern Mediterranean region by the Franks. The Muslims themselves occasionally tried to fight against the Crusaders at the beginning of the twelfth century but with no coordination (Carole Hillendbrand, 2005).

\section{SECOND CRUSADE}

The ascension 'Imad al-Din Zangi, the blue-eyed atabegh of Mosul (1127-1146) to the throne, marked the end of development and grandeur of Islam. Zangi was among the forerunners of the enemy to the Crusaders that culminated in the figure of Salah-al-Din (Saladin), and extended the period of the next halfcentury to Mamluk dynasty. Zangi was a 'beater hammer', the firmest to the force of the Crusaders that deserved to be fought and destroyed. The first battle he led took place in Edessa. Because of its proximity to Baghdad, as well as its control over the main route between Mesopotamia and the Mediterranean, the city became a fortress for the entire nation outside the Latin in Syria for half a century. After the attack for four weeks, Zangi captured it (in 1144) from Joesclin II. The takeover of this territory indirectly eliminated the breakdown of confidence among Muslims in Syria and Iraq. In Europe, this event marked a new period, which was usually called the Second Crusade (1147-1149), led by Conrad III of Germany and Louis VII of France. They successfully seized Damascus but this Crusade did not produce anything (Philip K. Hitti, 2008).

Zangi's power over Syrian territory was replaced by his son, Nur al-Din Mahmud (Nuruddin) Zangi. During the next phase of the revival of the Muslims, Nurruddin (d. 1174) combined a powerful political weapon with a very astute religious propaganda. In the context of personal and his family's ambition, Nuruddin gradually united Egypt and Syria and surrounded the remaining Frankish states, beginning with Antioch. Nuruddin conquered Damascus in 1154 and appointed himself supreme ruler of the Muslims in Syria. Both Nuruddin and the Crusaders then switched their attention to Egypt and the Fatimids who were suffering and weakened by internal conflicts 
(Carole Hillendbrand, 2005).

Nuruddin had a capable military leader named Syirkuh who had gained some military and diplomatic victories in Egypt, started up a political career by accepting the post of minister (1169) under the leadership of al-'Adid (11601171), the last Fatimid caliph. After Syirkuh died, he was succeeded by his nephew, Salah al-Din (religion savior, Saladin) Ibn Ayyub (Philip K. Hitti, 2008).

Al-Malik al-Nasir al-Sulthan Salah al-Din Yusuf was born in Tikrit, the Tigris, in 1138 under the guidance of the Kurds. Saladin had two major ambitions in his life, to replace Shia Islam with Sunni in Egypt, and to fight against the Franks in the Holy War. The efforts to realize the greatest ambition, i.e. to reach the Syrian Muslim sovereignty over the region, became a must. His efforts made his relationship with Nuruddin sour because in this area Nuruddin was in power. However, after the death of Nuruddin in 1174, Salah declared independence of Egypt and seized Syria and Isma'il which was only seven years old (Philip K. Hitti, 2008).

In May 1175, Saladin personally asked the Abbasid caliph, where the caliph was not strong enough to resist, to rule over the territories of Egypt, Morocco, Nubia, Western Arab, Palestine, and Central Syria. Ten years later, he conquered Mesopotamia, and made several kings his followers. Nuruddin's ambition to expel and destroy the Franks was realized by a very famous successor, Salah al-Din. This is a great victory for the Muslim army in which the peak of this victory was when Saladin recaptured Jerusalem on October 2, 1187. In 1187, only some parts of the Latin Kingdom of Jerusalem which was still controlled by the Crusaders, especially Tirus (Carole Hillendbrand, 2005).

\section{THIRD CRUSADE}

The Muslim force's victory in the second Crusade ignited the next Crusade. Three of the most powerful kings of the Western Europe, Frederick Barbarossa of the Holy Roman Empire, Philip of France and Richard the Lionheart of England, launched the third Crusade. This war began when the Crusaders attacked Acre which finally captured by the Crusaders in 1191. The Crusaders won despite this, also several other victories over Saladin. The third Crusade ended with an armistice in 1192, with an agreement that the Frank will dominate large parts of the sea, while Jerusalem remained under the Muslim rule (Carole Hillendbrand, 2005).

Saladin died a year later, but the Muslims were still superior and the states of the Crusaders were very weak. The Crusader states only controlled a small 
part of harbor and a small inland area. However, with these privileges, the Muslims did not expel the Crusaders. The Muslims instead treated them as rulers by making political alliances and trade agreements with them (Philip K. Hitti, 2008).

In 1228, Frederick II of Sicily arrived in Palestine to launch the Crusade. Sultan Ayyubiyah al-Kamil, whose family was threatened by internal disputes, preferred to negotiate rather than to fight and made an agreement with Frederick a year later, with the surrender of Jerusalem, Bethlehem, Nazareth, and other districts to the Crusaders. The third phase Crusade is also called the phase of Crusade that began to melt. Political compromises happened to trade along with the discovery of several coastal areas that were quite tempting for trade. The encounter between the West and Islam was no longer just a war, but diplomacy (economy) as well (Carole Hillendbrand, 2005).

\section{CRUSADE AND ITS EFFECT}

The Crusade, which lasted around three centuries, has formed an important chapter in the different but interconnected history of the West and the East. To the West, the Crusade was part of the evolution of the Medieval Period Western Europe. Its importance has long been recognized and by many generations of the Western scientists. As to the Muslims, the Medieval Period was pain, as the Crusade was none other than the Western European intervention in the region and in the lives of Muslims (Carole Hillendbrand, 2005).

In Karen Armstrong's view, even the Crusade against Islam in the Middle the East failed, at least the Muslims had been expelled from Spain. In 1499, the Muslims of Spain were given two choices: convert or be deported. Since then, for several centuries, Spain was free from Muslims. If seen from the Columbus incredible journey, Europeans were on the banks of the new world. Their insights became wide, exploring the world that had never been explored, geographically, intellectually, politically, economically, and socially (Karen Amstrong, 2000). Therefore, the Crusade reflects the triumph and destruction of the early modern period, the early phase of awakening for the Europeans later until today, and resulted in the Islamic world experiencing weakness and destruction of civilization, characterized by the destruction of the books of the works of Islamic scholars (Jatmika Sidik, 2004). According to M. Abdul Karim (2009), the energy drained away during the Crusade had caused an Islamic caliphate (Abbasid) in Baghdad to have no power to resist the attacks that came from the Mongols in 1253 by Hulagu Khan, grandson of Genghis Khan (Philip K. Hitti, 2008). 
Finally, all the grandeur, beauty and greatness of Baghdad which was first built by Caliph al-Mansur are now only a memory. Everything is like being carried away by the Tigris River, after the city was burnt down by the Mongols led by Hulagu Khan in 1258 AD. All the buildings of the city, including the golden palace, were destroyed. The Mongol troops were also destroyed the library which was a storehouse of knowledge and burnt the books kept in it (Badri Yatim, 2008). Hulagu killed many people and threw their bodies into the Tigris River, so that the river water turned red, then turned into brown because of the many books handwritten by scientists were dumped into it (M. Abdul Karim, 2009).

The Crusade is widely seen as the beginning of the revival of Europe and a defeat for Islamic world, but it does not mean that the Crusade has no positive impact at all for Islam. Among the positive sides to the Muslims is that because of the Crusade in $12^{\text {th }}$ century $\mathrm{AD}$, exchanges occurred between the traditions of the West and the East, for example, the use of spices from each country. The import of fabric from the Islamic countries has contributed to the international commerce. IN addition, Egypt and Syria served as the international trade traffic, and this has resulted in the abundant wealth of the Kingdom and the people (Jatmika Sidik, 2004).

\section{HISTORY OF THE CRUSADE AS A SOURCE OF INSPIRATION}

Harun Nasution divided the stages of the development of Islam into three major phases, i.e. first, the Classical Age of Islam (650-1250). This phase is the phase of the development of rational thought marked by the rise of Islam. Second, the Islamic Middle Ages (1250-1800). This phase began with the conquest of Baghdad earlier by the Mongols (1253) and ended at the time when Napoleon Bonaparte led France to the invasion of Egypt. In the Islamic world, this phase was characterized by the development of traditional thinking and the underdevelopment of Islam. On the contrary, it was the beginning of the rise of Europe, as mentioned above. Third, the Modern Age Islam (1800s - now). In this phase was marked by the development of Europe (the West) in the world of science and technology, the backwardness of Islam, and the Islamic world by European colonialism and the West (Harun Nasution, 1996).

If carefully traced, the history, underdevelopment and oppression of the Islamic world today are inseparable from the history of the Crusade. Bernard Lewis showed us that the West was once underdeveloped compared to the East, but the West responded by developing science and technology. To keep up with the underdevelopment, the West tried the institutionalization doubt, because it gave birth to an idea to achieve the level of advancement. Lewis did 
not find this in the Islamic world in responding to the progress of the West. In fact, the institutionalization of terrorism arose from Islamic fundamentalists in response to the Western progress and modernization in the Muslim world, the Middle the East in particular.

Therefore, the Islamic world should learn from the West to catch up by building a culture of science and knowledge. Thus, the culture must be built with a strong science in the Islamic world, of course. Philip K. Hitti wrote the book History of the Arabs that contains 981 pages. This indicates a serious scientific culture in the world of the Western science. If you read the preface in it, the book he wrote was based on research he conducted in the Arab world for more than ten years (1927-1937).

The question is, are there any scientists of the Islamic world that is able to match the caliber of work produced by Hitti? If not, it shows that we have yet to possess the cultural knowledge of the West. Another book History of Modern Indonesia, 1200-2004 was written by M.C. Ricklefs of the Australian National University. It would be difficult for us to find a serious work of the caliber of History of the Arabs and History of Modern Indonesia, 1200-2004 on the shelves of our library written by Muslim scientists. This is an indicator that we have not been able to compete with the scientific culture of the West. Thus, we have not learnt from history that the West destroyed the Islamic civilization by destroying the library and they built a civilization with a strong library culture (scientific culture). This is in line with what was said by Milan Kundera, of the Czech Republic, "If you wish to destroy a nation, it's easy; destroy its library."

\section{CONCLUSION}

The consequences of the Crusade are indeed beneficial to Europeans (the West) to awaken and it can be seen until now, but not for the East (Islam). In Hillenbrand's view, it is because of the different response of both parties. To the Westerners, the Crusade is a popular field of study that deals with the study of medieval West. Therefore, there is seriousness to examine the historical events. As for the Muslims in the East, the Crusade in fact plays a temporary role but not forgotten. The Crusade has influenced the awareness of Muslims until now (of the intervention of European Christians). However, the knowledge produced of the Crusade in the Middle the East is very poor, Hillendbrand argued. With this conclusion, the West and the East actually have interests in the study of the history of the Crusade. 


\section{REFERENCES}

Armstrong, Karen. 2000. Berperang Demi Tuhan, Fundamentalisme dalam Islam, Kristen, dan Yahudi. Bandung: Mizan.

Fuller, Graham. 2011. A World Without Islam. New York: Back Boy Books.

Hillendbrand, Carole. 2005. Perang Salib, Sudut Pandang Islam. Jakarta: Serambi Ilmu Semesta (translation).

Hitti, Philip K. 2008. History of the Arabs. Jakarta: Serambi Ilmu Semesta (translation).

Jatmika, Sidik. 2004. Politik Timur Tengah (Bahan Ajar Perkuliahan). Yogyakarta: UMY.

Johnson, James T. 2002. Ide Perang Suci. Yogyakarta: Qalam (translation).

Karim, Abdul, M. 2009. Sejarah Pemikiran dan Peradaban Islam. Yogyakarta: Pustaka Book Publisher.

Kennedy, Hugh. 2008. The Great Arab Conquests, Penaklukan Terbesar Dalam Sejarah Islam Yang Mengubah Dunia. Tangerang: Alvabet (translation).

Nasution, Harun. 1996. Islam Rasional, Gagasan dan Pemikiran. Bandung: Penerbit Mizan.

Yatim, Badri. 2008. Sejarah Peradaban Islam. Jakarta: PT RajaGrafindo Persada. 